\title{
Akuntabilitas Kinerja Aparatur Sipil Negara (ASN) Di Kantor Kementerian Agama Kota Manado
}

\author{
Nona Sandra Polihu \\ Program Studi Magister Adminitrasi Negara \\ Program Pasca Sarjana \\ Universitas Negeri Manado \\ nonasandra97@gmail.com
}

\begin{abstract}
Abstrak - Penelitian ini bertujuan untuk mengetahui, mendeskripsikan dan menganalisis Akuntabilitas Kinerja Aparatur Sipil Negara (ASN) Di Kantor Kementerian Agama Kota Manado. Fokus Penelitian terkait dengan Kinerja Aparatur Sipil Negara dan Pengawasan Internal dilingkungan Kementerian Agama Kota Manado, Metode yang digunakan dalam Penelitian ini adalah metode penelitian kualitatif. Dari Penelitian ini diperoleh kesimpulan bahwa : Masih belum terlalu dipahaminya landasan ukuran ataupun aturan yang dipakai untuk ASN dalam menjalankan tugas dan fungsinya dan adanya Pegawai ASN yang masih lambat dalam menjalankan TUPOKSInya. ASN yang ada masih kurang menjalankan target kerja secara maksimal sehingga hasil kerja belum bisa dicapai karena adanya tindakan pelanggaran oleh ASN bahkan mengabaikan prosuder ataupun TUPOKSI yang telah diberikan kepada ASN.

Kata Kunci : Akuntabilitas Kinerja, Pengawasan.
\end{abstract}

\section{PENDAHULUAN}

Pertanggung jawaban terhadap pelaksanaan tugas dan fungsi oleh penyelenggara pemerintahan merupakan suatu hal yang mutlak untuk dilakukan kepada public atau masyarakat. Hal ini dilatari oleh tugas dan fungsi serta kewenangan yang dimiliki merupakan amanat yang diberikan oleh rakyat sebagai pemilik kekuasaan dan pemegang kedaulatan yang dijamin oleh konstitusi. Sebab itu penyelenggaran pemerintahan dengan kekuasaan dan kewenangan yang diberikan melalui proses system demokrasi dan dengan penggunaan sumber daya keuangan yang bersumber dari masyarakat berkewajiban untuk mempertanggung jawabkan (accountability) kepada publik atau masyarakat itu sendiri. Akuntabilitas menjadi landasan bagi proses untuk penyelenggaraan kepemerintahan (good governance) dan keberadaannya menentukan pelaksanaan tugas dan tanggungjawab yang benar-benar akuntabel.

Aparatur sipil Negara (ASN) dalam pelaksanaan tugas dan tanggungjawabnya, perlu diukur kinerjanya dengan jelas. Dalam kaitan ini, Levine, mengusulkan ada tiga konsep penting dalam pengukuran kinerja birokrasi public terkait dengan tugas dan tanggungjawabnya yaitu konsep akuntabilitas (accountability), responsibilitas (responsibility), dan responsivitas (responsiveness). vitas (responsiveness). Ketiga konsep tersebut dapat diuraikan sebagai berikut [1]:

Pertama, Akuntabilitas (accountability), berkenaan dengan standar eksternal yang menentukan kebenaran suatu tindakan oleh administrasi negara. Akuntabilitas public menunjuk seberapa besar kebijakan dan kegiatan organisasi public tunduk pada para pejabat politik yang dipilih oleh rakyat, karena dilihat dari dimensi kinerja birokrasi public tidak bias dilihat dari ukuran internal yang dikembangkan oleh birokrasi public atau pemerintah, tetapi juga dinilai dan ukuran eksternal seperti nilai-nilai dan norma-norma yang berlaku di dalam masyarakat.

Kedua, Responsibilitas atau (responsibility) berkenan dengan standar professional dan kompetisi teknis yang dimiliki administrator Negara dalam menjalani tugasnya. Administrator Negara dinilai responsible jika perilakunya memiliki standar profesionalisme atau kompetensi teknis yang tinggi.

Tiga, Responsivitas, merupakan kemampuan organisasi untuk mengenali kebutuhan masyarakat, menyusun agenda dan prionitas pelayanan dalam pengembangan program-program pelayanan public sesuai dengan kebutuhan dan aspirasi masyarakat.

Akuntabilitas Kinerja Aparatur Sipil Negara (ASN) masih terkesan belum prima. 
Pelayanan yang diberikan terlalu lamban, berbelit-belit, lama, tidak terbuka, kurangnya koordinasi, karakter aparatur pemerintah yang tidak terpuji, korup, tidak bertanggung jawab, boros waktu, tenaga dan biaya sehingga membuat masyarakat yang dilayani menjadi jenuh dan pada akhirnya menghadirkan reaksi emosional dari masyarakat yang beragam, [2]. Akuntabilitas Kinerja Instansi Pemerintah adalah perwujudan kewajiban suatu instansi pemerintah untuk mempertanggungjawabkan

keberhasilan/kegagalan pelaksanaan misi organisasi dalam mencapai tujuan dan sasaran yang telah ditetapkan melalul alat pertanggungjawaban secara periodik.

Akuntabilitas Publik merupakan kewajiban bagi penyelenggara kebijakan (pembuatan, pelaksanaan dan penilaian) untuk mempertanggungjawabkan segala tindakannya itu kepada publik, baik tindakan yang berhasil terlebih lagi tindakan yang gagal. Dalam pelaksanaan akuntabilitas di lingkungan instansi pemerintah perlu memperhatikan prinsip-pninsip berikut: (a), Harus ada komitmen dari pimpinan dan seluruh staf instansi untuk melakukan pengelolaan pelaksanaan misi agar akuntabel (b). Harus merupakan suatu sistem yang dapat menjamin penggunaan. Sumber daya secara konsisten dengan peraturan perundang undangan yang berlaku. (c). Harus dapat menunjukkan tingkat pencapaian tujuan dan sasaran yang ditetapkan. (d). Harus berorientasi pada pencapaian visi dan misi serta hasil dan manfaat yang diperoleh. (e). Harus jujur, objektif, transparan dan inovatif sebagai kata lisator perubahan manajemen dalam bentuk pemutakhiran metode dan teknik pengukuran kinerja dan penyusunan laporan akuntabilitas, [3].

Akuntabilitas Kinerja terkait pengawasan Tatakerja dan prosedur Tata kerja.Tata kerja disini dimaksudkan sebagai caracara pelaksanaan kerja yang efisien mengenai satu atau serangkaian tugas dengan memperhatikan segi-segi tujuan, peralatan, fasilitas, tenaga, waktu, ruang, dan biaya yang tersedia [4]. Dan Prosedur Kerja; adalah rangkaian tata kerja yang berkaitan satu sama lain, sehingga menunjukkan adanya urutan secara jelas dan pasti serta cara-cara yang harus ditempuh dalam rangka penyelesaian suatu bidang tugas.Sistem Kerja disini diartikan dengan rangkaian tata kerja dan prosedur kerja yang membentuk suatu kebulatan pola kerja tertentu dalam rangka mencapai hasil kerja yang diharapkan. Dan kewajiban, disini diartikan sebagai aparatur penyelenggara pelayanan umum untuk mengambil tindakan dalam rangka pelaksanaan tugas dan fungsi sesuai dengan peraturan perundang-undangan yang berlaku. Dalam rangka memuaskan masyarakat sebagai pelanggan, kewajiban bukan hanya melekat pada pejabat, tetapi setiap aparatur dalam lingkungan kerja ketika bertemu dengan pelanggan [5].

Pengawasan merupakan fungsi manajerial yang keempat setelah perencanaan, pengorganisasian, dan pengarahan. Sebagai salah satu fungsi manajemen, mekanisme pengawasan di dalam suatu organisasi memang mutlak diperlukan. Pelaksanaan suatu rencana atau program tanpa diiringi dengan suatu system pengawasan yang baik dan berkesinambungan, jelas akan mengakibatkan lambatnya atau bahkan tidak tercapainya sasaran dan tujuan yang telah ditentukan.

Prosedur Pengawasan telah diatur melalui Peraturan Menteri Agama Republik Indonesia Nomor 41 tahun 2016 Tentang Pengawasan Internal Pada Kementerian Agama, Prosedur pengawasan disini mencerminkan bahwa Pengawasan merupakan tindakan membandingkan antara hasil dalam kenyataan (dassein) dengan hasil yang diinginkan (das sollen), yang dilakukan dalam rangka melakukan koreksi atas penyimpangan-penyimpangan yang terjadi dalam kegiatan manajemen. Pengawasan sebagai salah satu tindakan yang harus dilakukan pejabat publik dimana pengawasan senantiasa diupayakan agar supaya seluruh rencana ataupun program dapat berlangsung dengan baik [6].

Jika dalam pelaksanaan terjadi penyimpangan dari rencana ataupun program maka harus diarahkan kembali sesuai dengan rencana agar supaya pelaksanaan kegiatan maksimal dan mencapai tujuan yang ditentukan. Pentingnya pelaksanaan pengawasan, sebagaimana dikemukakan Siagian, pengawasan adalah: "Proses pengamatan daripada pelaksanaan seluruh kegiatan organisasi untuk menjamin agar supaya semua pekerjaan yang sedang dilakukan berjalan sesuai dengan rencana yang telah ditentukan sebelumnya." Ciri terpenting dari konsep yang dikemukan oleh Siagian ini adalah bahwa pengawasan hanya dapat diterapkan bagi pekerjaan-pekerjaan yang sedang berjalan dan tidak dapat diterapkan untuk 
pekerjaan-pekerjaan yang sudah selesai dilaksanakan [7].

Kementerian Agama memiliki tugas pokok untuk mengatur kehidupan beragama dengan tidak mencampuri urusan intern agama, tetapi menyangkut aktualisasi kehidupan beragama di masyarakat yang meliputi pelayanan kepada umat beragama dan penguatan lembagalembaga keagamaan. Dalam rangka menjalankan good governance serta untuk lebih mampu memberikan pelayanan kepada masyarakat dalam bidang yang menjadi tugas dan tanggung jawabnya, maka Kementerian Agama telah menetapkan tema sentral di bidang reformasi birokrasi khususnya di lingkungan Kementerian Agama, yaitu "Dengan Reformasi Administrasi Kementerian Agama Siap Mewujudkan Pemerintahan Yang Bersih" [8].

Reformasi Administrasi yang sedang bergulir di Kementerian Agama telah memiliki arah untuk implementasinya dengan melalui beberapa tahapan yang harus dilakukan yaitu : (1) penataan organisasi; (2) perbaikan sistem tata laksana; (3) peningkatan sumber daya manusia; dan (4) perbaikan struktur penggajian (remunerasi). Dari skema reformasi birokrasi di Kementerian Agama tersebut, tampak bahwa peningkatan Sumber Daya Manusia baik dalam segi kuantitas maupun kualitasnya merupakan agenda yang harus dapat di implementasikan di setiap bagian organisasi Kementerian Agama [8]. Namun visi dan misi yang ditetapkan terdapat kesenjangan antara kenyataan dan harapan, terlebih terkait akuntabilitas kinerja dan bentuk poengawasa secara internal.

Dari data hasil observasi persoalan yang sering muncul yang dapat teridentifikasi melalui observasi awal di Kantor Kementerian Agama Kota Manado. Permasalahan yang sering dihadapi Kementerian Agama Kota Manado berkaitan dengan Akuntabilitas Kinerja yang belum maksimal, dimana terdapat pegawai yang sering dating terlambat tapi tidak mendapatkan teguran dan pengurangan uang makan hanya karena pegawai tersebut sudah senior atau bahkan seorang yang memiliki jabatan tetentu. Sedangkan pegawai junior yang pernah terlambat atau lupa tidak absen sidik jari uang makannya tidak dibayarkan sama sekali, terkesan adanya tebang pilih dalam pelaksanaan sanksi jika pegawai tidak melakukan kinerja yang baik. Dalam Peraturan Pemerintah Nomor 53 Tahun 2010 tentang Disiplin Pegawai Negeri Sipil telah disebutkan disiplin Pegawai Negeri Sipil (PNS) atau Aparatur Sipil Negara (ASN) adalah kesanggupan Pegawai Negeri Sipil/Aparatur Sipil Negara untuk menaati kewajiban dan menghindari larangan yang ditentukan dalam peraturan perundang-undangan dan/atau peraturan kedinasan yang apabila tidak ditaati atau dilanggarakan dijatuhi hukuman disiplin [9].

Hukuman disiplin adalah hukuman yang dijatuhkan kepada PNS/ASN karena melanggar peraturan disiplin PNS/ASN (pasal 1 ayat 4).Namun dalam pelaksanaannya, belum dilaksanakan. Pengawasan secara internal oleh atasan terhadap pelaksanaan tugas oleh pelaksana. Dalam hal kehadiran ASN/PNS hanya melakukan kewajiban mengisi daftar hadir, sedangkan waktu diantaranya terkadang ASN/PNS tidak berada ditempat. Ketersediaan sumber daya manusia (SDM) yang handal dan kompetitif juga masih kurang serta fasilitas yang belum mendukung dalam kelancaran pekerjaan. Rendahnya kinerja dan lambannya merespons aspirasi merupakan hal yang menunjukkan bahwa birokrasi terkesan kaku dan tidak fleksibel. Hal ini terjadi disebabkan salah satunya pada lemahnya pengawasan internal pada kinerja Kantor Kementerian Agama Kota Manado.

Kinerja aparatur Sipil Negara (ASN) menjadi isu strategis karena perbaikan kinerja memiliki implikasi yang luas dalam mencapai tujuan organisasi, maka dituntut memacu reformasi Aparatur Sipil Negara menuju capaian kinerja yang efektif, efisien, ekonomis, dan akuntabel. Belum maksimalnya kinerja aparatur Sipil Negara (ASN) seperti yang diutarakan diatas menjadi salah satu factor lemahnya pengawasan internal sehingga tidak efektifnya dan kurang akuntabelnya kinerja Aparatur Sipil Negara (ASN) di lingkungan Kerja di Kantor Kementerian Agama Kota Manado, sehingga mendorong peneliti untuk menggali lebih mendalam permasalahan ini sebagai penelitian Tesis dengan mengambil tema: "Akuntabilitas Kinerja Aparatur Sipil Negara (ASN) Di Kantor Kementerian Agama Kota Manado.”.

Berdasarkan penjelasan diatas, dapat dirumuskan masalah sebagai berikut:

1. Bagaimanakah Akuntabilitas Kinerja Aparatur Sipil Negara (ASN) Pada Kantor Kementerian Agama Kota Manado ?

2. Bagaimanakah bentuk pengawasan internal terkait kinerja Aparatur Sipil Negara (ASN) Pada Kantor Kementerian Agama Kota Manado? 
Sehingga penelitian ini bertujuan untuk mendeskripsikan, menganalisis dan menginterpretasikan Akuntabilitas Kinerja dan pengawasan Aparatur Sipil Negara (ASN) Pada Kantor Kementerian Agama Kota Manado.

Sehingga bisa bermanfaat secara teoritis yaitu memberikan masukan secara positif bahkan dapat menjadi bekal pengetahuan yang berguna dalam perkembangan ilmu pengetahuan, dan secara praktis dapat memberikan kontribusi positif bagi ASN Pada Kantor Kementerian Agama Kota Manado.

\section{METODE PENELITIAN}

\section{A. Pendekatan Penelitian}

Penelitian ini menggunakan metode kualitatif. Peneliti tertarik menggunakan metode kualitatif karena ingin mengetahui secara mendalam tentang Akuntabilitas Kinerja dan Pengawasan ASN pada Kantor Kementerian Agama Kota Manado. dengan menggunakan metode kualitatif, peneliti dapat secara langsung melakukan wawancara sehingga dapat memperoleh data yang akurat dan sesuai fakta yang terjadi dilapangan.

\section{B. Fokus dan Deskripsi Penelitian}

Fokus penelitian pertama terkait dengan Akuntabilitas Kinerja Aparatur Sipil Negara (ASN) dan fokus yang kedua adalah terkait dengan pengawasan internal kinerja Aparatur Sipil Negara (ASN) Pada Kantor Kementerian Agama Kota Manado.

\section{Lokasi Penelitian}

Penelitian berlokasi di Kantor Kementerian Agama Kota Manado yang sangat berkaitan dengan Akuntabilitas Kinerja dan Pengawasan Internal.

\section{Sumber Data}

Berdasarkan rumusan masalah yang ada maka sumber data berasal dari hasil wawancara terhadap informan kunci yaitu : Kepala Kantor Kementerian Agama Kota Manado, Kepala Sub Bagian (2 Orang), Pegawai (3 Orang), Stakeholder yang menerima pelayanan.

\section{E. Teknik Pengumpulan Data}

Data dikumpulkan peneliti dengan cara melakukan wawancara kepada informan kunci dan melakukan pengamatan terkait dengan Akuntabilitas Kinerjadan Pengawasan ASN.

\section{F. Analisis Data}

Dalam penelitian kualitatif, analisis data dilakukan sejak awal sepanjang proses penelitian berlangsung. Dalam penelitian ini digunakan analisis data kualitatif, Miles dan Huberman dengan prosedur, reduksi data, penyajian data, menarik kesimpulan atau verifikasi.

\section{HASIL PENELITIAN}

\section{A. Deskripsi Hasil Penelitian}

1. Akuntabilitas Kinerja Pegawai Aparatur Sipil Negara (ASN) di Kantor Kementerian Agama Kota Manado

Persoalan yang sering muncul yang dapat teridentifikasi di Kantor Kementerian Agama Kota Manado. Permasalahan yang sering dihadapi Kementerian Agama Kota Manado berkaitan dengan Akuntabilitas Kinerja yang belum maksimal, dimana terdapat pegawai yang sering datang terlambat tapi tidak mendapatkan teguran dan pengurangan uang makan hanya karena pegawai tersebut sudah senior atau bahkan seorang yang memiliki jabatan tetentu. Sedangkan pegawai junior yang pernah terlambat atau lupa tidak absen sidikjari uang makannya tidak dibayarkan sama sekali, terkesan adanya tebang pilih dalam pelaksanaan sanksi jika pegawai tidak melakukan kinerja yang baik, Dalam Peraturan Pemerintah Nomor 53 Tahun 2010 tentang Disiplin Pegawai Negeri Sipil telah disebutkan disiplin Pegawai Negeri Sipil (PNS) atau Aparatur Sipil Negara (ASN) adalah kesanggupan Pegawai Negeri Sipil/Aparatur Sipil Negara untuk menaati kewajiban dan menghindari larangan yang ditentukan dalam peraturan perundangundangan dan/atau peraturan kedinasan yang apabila tidak ditaati atau dilanggar akan dijatuhi hukuman disiplin.

Prosedur Pengawasan yang telah diatur melalui Peraturan Menteri Agama Republik Indonesia Nomor 41 tahun 2016 Tentang Pengawasan Internal Pada Kementerian Agama, Prosedur pengawasan disini mencerminkan bahwa Pengawasan merupakan tindakan membandingkan 
antara hasil dalam kenyataan (dassein) dengan hasil yang diinginkan (das sollen), yang dilakukan dalam rangka melakukan koreksi atas penyimpangan-penyimpangan yang terjadi dalam kegiatan manajemen. Pengawasan sebagai salah satu tindakan yang harus dilakukan pejabat publik dimana pengawasan senantiasa diupayakan agar supaya seluruh rencana ataupun program dapat berlangsung dengan baik.

Berdasarkan informasi yang diberikan informan terkait kemampuan yang diperlihatkan dan prestasi yang dicapai oleh ASN bisa ditemukan bahwa prestasi yang ditunjukan hanya melalui laporan - laporan pertanggungjawabakan dari Sasaran Kinerja Pegawai (SKP) dan itupun tergantung dari pribadi masingmasing ASN bahkan didapati tupoksi bagi ASN tidak dijalankan secara maksimal sehingga menghambat pencapaian prestasi bahkan promosi jabatan sedangkan dalam aturan dijelaskan untuk mendapatkan promosi dilihat dari kompetensi, kualifikasi, dan persyaratan yang dibutuhkan oleh jabatan, penilaian atas prestasi kerja, kepemimpinan, kerja sama, kreativitas, dan pertimbangan dari tim penilai kinerja PNS pada Instansi Pemerintah, tanpa membedakan jender, suku, agama, ras, dan golongan yang ada.

Kemudian terkait prosedur yang apa sudahdiketahui oleh masing-masing pegawai dapat disimpulkan bahwa para ASN memang sudah mengetahui prosuder yang ada tetapi masih saja mengabaikan bahkan melakukan pelanggaran baik itu prosuder atau TUPOKSI yang diberikan karena masih adanya ketidakpatuhan para ASN terkait prosuder yang telah ditetapkan dan ASN yang ada masih kurang disiplin dalam menjalankan prosuder yang ada padahl hal tersebut merupakan kewajiban yang harus dilaksanakan oleh ASN itu sendiri agar tujuan dan pelayanan kepada masyarakat dapat tercapai secara maksimal.

2. Bentuk pengawasan internal Kinerja Aparatur Sipil Negara (ASN) Pada Kantor Kementerian Agama Kota Manado
Pengawasan merupakan fungsi manajerial yang keempat setelah perencanaan, pengorganisasian, dan pengarahan. Sebagai salah satu fungsi manajemen, mekanisme pengawasan di dalam suatu organisasi memang mutlak diperlukan. Pelaksanaan suatu rencana atau program tanpa diiringi dengan suatu system pengawasan yang baik dan berkesinambungan, jelas akan mengakibatkan lambatnya atau bahkan tidak tercapainya sasaran dan tujuan yang telah ditentukan.

Prosedur Pengawasan telah diatur melalui Peraturan Menteri Agama Republik Indonesia Nomor 41 tahun 2016 Tentang Pengawasan Internal Pada Kementerian Agama, Prosedur pengawasan disini mencerminkan bahwa Pengawasan merupakan tindakan membandingkan antara hasil dalam kenyataan (dassein) dengan hasil yang diinginkan (das sollen), yang dilakukan dalam rangka melakukan koreksi atas penyimpangan-penyimpangan yang terjadi dalam kegiatan manajemen. Pengawasan sebagai salah satu tindakan yang harus dilakukan pejabat publik dimana pengawasan senantiasa diupayakan agar supaya seluruh rencana ataupun program dapat berlangsung dengan baik.

Temuan yang ditemukan adalah dimana para ASN mampu menyelesaikan pekerjaan yang sulit dan walaupun terbilang sulit memang harus berusaha dilakukan dan diselesaikan secara baik dan juga pekerjaan yang ada tentunya sudah sesuai dengan tugas dan fungsi masing-masing yang diberikan kepada Aparatur Sipil Negara baik itu oleh pimpinan yang ada di Kemenag Manado ataupun sesuai dengan aturan yang telah ditetapkan tetapi tidak bisa dipungkiri bahwa masih adanya pegawai yang tidak menyelesaikan pekerjaan yang telah diberikan. Dari hasil temuan diatas didapati memang masih banyak kesengjangan yang terjadi.

\section{B. Pembahasan}

\section{Akuntabilitas Kinerja Pegawai}

Akuntabilitas merupakan aktivitas untuk memberikan penjelasan dan alasan pembenaran 
atas tindakan (cara) yang dilakukan dalam menggunakan kekuasaan, dan mengambil tindakan korektif ketika terjadi kesalahan.Akuntabilitas Kinerja Instansi Pemerintah adalah perwujudan kewajiban suatu instansi pemerintah untuk mempertanggungjawabkan keberhasilan / kegagalan pelaksanaan misi organisasi dalam mencapai tujuan dan sasaran yang telah ditetapkan melalul alat pertanggungjawaban secara periodik.

Akuntabilitas Publik merupakan kewajiban bagi penyelenggara kebijakan (pembuatan, pelaksanaan dan penilaian) untuk mempertanggungjawabkan segala tindakannya itu kepada publik, baik tindakan yang berhasil terlebih lagi tindakan yang gagal. Akuntabilitas Kinerja terkait pengawasan Tatakerja dan prosedur Tata kerja. Tata kerja disini dimaksudkan sebagai cara-cara pelaksanaan kerja yang efisien mengenai satu atau serangkaian tugas dengan memperhatikan segisegi tujuan, peralatan, fasilitas, tenaga, waktu, ruang, dan biaya yang tersedia.

Akuntabilitas Kinerja Instansi Pemerintah adalah perwujudan kewajiban suatinstansi pemerintah mempertanggungjawabkan keberhasilan / kegagalan pelaksanaan misi organisasi dalam mencapai tujuan dan sasaran yang telah ditetapkan melalul alat pertanggungjawaban secara periodik.

Jadi, Akuntabilitas Publik merupakan kewajiban bagi penyelenggara kebijakan (pembuatan, pelaksanaan dan penilaian) untuk mempertanggungjawabkan segala tindakannya itu kepada publik, baik tindakan yang berhasil terlebih lagi tindakan yang gagal. Dalam pelaksanaan akuntabilitas di lingkungan instansi pemerintah perlu memperhatikan prinsip-pninsip berikut: (a), Harus ada komitmen dari pimpinan dan seluruh staf instansi untuk melakukan pengelolaan pelaksanaan misi agar akuntabel (b). Harus merupakan suatu sistem yang dapat menjamin penggunaan. Sumbersumber daya secara konsisten dengan peraturan perundang undangan yang berlaku. (c). Harus dapat menunjukkan tingkat pencapaian tujuan dan sasaran yang ditetapkan. (d). Harus berorientasi pada pencapaian visi dan misi serta hasil dan manfaat yang diperoleh. (e). Harus jujur, objektif, transparan dan inovatif sebagai katalisator perubahan manajemen dalam bentuk pemutakhiran metode dan teknik pengukuran kinerja dan penyusunan laporan akuntabilitas.
Ada kesengjangan yang terjadi mulai dari ASN di Kemenag Manado sudah menjalankan TUPOKSI secara bertanggung jawab tetapi ASN kurang mengetahui secara detail isi TUPOKSI, masih belum terlalu memahami landasan ukuran ataupun aturan yang dipakai untuk ASN dalam menjalankan tugas dan fungsinya, adanya Pegawai ASN yang masih lambat dalam menjalankan TUPOKSInya kemudian prestasi yang ditunjukan hanya melalui laporan-laporan pertanggungjawaban dari Sasaran Kinerja Pegawai (SKP) dan itupun tergantung dari pribadi masing-masing ASN.

Selanjutnya adanya kesenjangan yang terjadi dalam penelitian ini yaitu ASN yang ada masih kurang menjalankan target kerja secara maksimal sehingga hasil kerja belum bisa dicapai. Tugas sudah dilakukan secara cukup baik tetapi para ASN masih kurang memahami secara detail prosuder apa saja yang dipakai untuk ASN. Kemudian Masih adanya tindakan pelanggaran oleh ASN bahkan mengabaikan prosuder ataupun TUPOKSI yang telah diberikan kepada ASN.

\section{Bentuk Pengawasan internal Kinerja}

Kelemahan kinerja antara lain adalah lemahnya pengawasan. Pengawasan merupakan fungsi manajerial yang keempat setelah perencanaan, pengorganisasian, dan pengarahan. Sebagai salah satu fungsi manajemen, mekanisme pengawasan di dalam suatu organisasi memang mutlak diperlukan. Pelaksanaan suatu rencana atau program tanpa diiringi dengan suatu system pengawasan yang baik dan berkesinambungan, jelas akan mengakibatkan lambatnya atau bahkan tidak tercapainya sasaran dan tujuan yang telah ditentukan.

Berdasarkan hasil penelitian jika dikaitkan dengan teori tersebut didapat bahwa adanya kesengjangan yang terjadi masih adanya pembagian tugas yang tidak disampaikan secara jelas kepada beberapa pegawai, para egawai sudah menyelesaikan tugas secara cepat dan tepat tetapi memang masih ada beberapa ASN yang tidak bisa menyelesaikan tugas secara tepat waktu karena juga ada kendala-kendala yang dihadapi ASN seperti pengelola data dan verifikasi pendaftaran Haji yang mangalami hambatan pada penginputan calon Jemaah Haji yang ada. Kemudian ASN yang ada sudah 
mampu melaksanakan dan menyelesaikan pekerjaan yang sulit baik itu diberikan oleh pimpinan ataupun sesuai dengan tupoksi yang telah ditetapkan.

Permasalahan yang sering dihadapi Kementerian Agama Kota Manado berkaitan dengan Akuntabilitas Kinerja yang belum maksimal, dimana terdapat pegawai yang sering datang terlambat tapi tidak mendapatkan teguran dan pengurangan uang makan hanya karena pegawai tersebut sudah senior atau bahkan seorang yang memiliki jabatan tetentu. Sedangkan pegawai junior yang pernah terlambat atau lupa tidak absen sidikjari uang makannya tidak dibayarkan sama sekali, terkesan adanya tebang pilih dalam pelaksanaan sanksi jika pegawai tidak melakukan kinerja yang baik, Dalam Peraturan Pemerintah Nomor 53 Tahun 2010 tentang Disiplin Pegawai Negeri Sipil telah disebutkan disiplin Pegawai Negeri Sipil (PNS) atau Aparatur Sipil Negara (ASN) adalah kesanggupan Pegawai Negeri Sipil/Aparatur Sipil Negara untuk menaati kewajiban dan menghindari larangan yang ditentukan dalam peraturan perundang-undangan dan/atau peraturan kedinasan yang apabila tidak ditaati atau dilanggar akan dijatuhi hukuman disiplin (pasal 1 ayat 1 ).

Hukuman disiplin adalah hukuman yang dijatuhkan kepada PNS/ASN karena melanggar peraturan disiplin PNS/ASN (pasal 1 ayat 4).Namun dalam pelaksanaannya, belum dilaksanakan.Pengawasan secara internal oleh atasan terhadap pelaksanaan tugas oleh pelaksana. Dalam hal kehadiran ASN/PNS hanya melakukan kewajiban mengisi daftar hadir, sedangkan waktu diantaranya terkadang ASN/PNS tidak berada ditempat.ketersediaan sumber daya manusia (SDM) yang handal dan kompetitif juga masih kurang serta fasilitas yang belum mendukung dalam kelancaran pekerjaan. Rendahnya kinerja dan lambannya merespons aspirasi merupakan hal yang menunjukkan bahwa birokrasi terkesan kaku dan tidak fleksibel. Hal ini terjadi disebabkan salahsatunya pada lemahnya pengawasan internal pada kinerja Kantor Kementerian Agama Kota Manado.Kinerja aparatur Sipil Negara (ASN) menjadi isu strategis karena perbaikan kinerja memiliki implikasi yang luas dalam mencapai tujuan organisasi, maka dituntut memacu reformasi Aparatur Sipil Negara menuju capaian kinerja yang efektif, efisien, ekonomis, dan akuntabel. Belum maksimalnya kinerja aparatur Sipil Negara (ASN) seperti yang diutarakan diatas menjadi salah satu faktor lemahnya pengawasan internal sehingga tidak efektifnya dan kurang akuntabelnya kinerja Aparatur Sipil Negara (ASN) di lingkungan Kerja di Kantor Kementerian Agama Kota Manado. Dari berbagai permasalahan kinerja maka perlu disusun LAKIP sebagai salah satu indikator atau alat bantu agar tercapainya kinerja yang maksimal.

\section{Rencana Strategis Kementerian Agama Kota Manado}

Penyusunan Renstra Kementerian Agama Kota Manado mengacu pada RPJMN Tahun 2015-2020, Renstra Kemenag RI dan Renstra Kanwil Kemenag Provinsi Sulawesi Utara. Bagian pokok rencana strategis kementerian Kota Manado adalah menjabarkan arah kebijakan dan strategi kementerian Agama RI yang selanjutnya akan dijabarkan dalam bentuk program yang hendak dicapai dan indikator pencapaiannya (outcomes), kegiatan strategis, keluaran (output); strategi implementasi dan pendanaan. Rencana Strategis Kementerian Agama Kota Manado 2015-2020 disusun berdasarkan kerangka logis dan alur berpikir, sebagaimana telah diuraikan tersebut diatas. Proses penyusunan juga telah dilakukan secara partisipatif antar unit-unit dan melibatkan pegawai.

Kementerian Agama Kota Manado telah membuat penetapan kinerja tahun 2020 secara berjenjang sesuai dengan kedudukan, tugas, dan fungsi yang ada. Penetapan kinerja ini telah mengacu pada Renstra Kementerian Agama RI dan Kota Manado serta RK-AKL Tahun 2020. Oleh karena itu indikator-indikator kinerja dan target tahunan yang digunakan dalam penetapan kinerja ini adalah indikator kinerja utama tingkat kementerian yang telah ditetapkan dan telah diintegrasikan dalam Renstra Kementerian Agama Kota Manado tahun 2015-2020. Tolak ukur keberhasilan sasaran strategis Kementerian Agama Kota Manado memang tidak seluruhnya dapat dituangkan dalam grafik dan angka-angka yang bersifat kuantitatif. Dari lima sasaran strategis yang ingin dicapai Kementerian Agama Kota Manado sebagaimana telah ditetapkan dalam Renstra 2015-2019, empat diantaranya mencakup dimensi pembangunan manusia dan 
perubahan perilaku masyarakat yang tentu pencapaiannya membutuhkan proses dan waktu.

\section{KESIMPULAN}

Berdasarkan hasil data Penelitian yang telah diuraikan maka dapat disimpulkan sebagai berikut:

Landasan ukuran ataupun aturan yang dipakai untuk ASN dalam menjalankan tugas dan fungsinya masih lambat dalam menjalankan TUPOKSInya. sehingga hasil kerja belum bisa dicapai karena adanya tindakan pelanggaran oleh ASN bahkan mengabaikan prosuder ataupun TUPOKSI yang telah diberikan kepada ASN.

\section{REFERENSI}

[1] N. Levine, "Buku Pelajaran Parasitologi Veteriner," Yogyakarta: Gadjah Mada University Press, 1990.

[2] Jauhar \& Muhammad, "Implementasi PAIKEM dari BEHAVIORISTIK sampai KONTRUKTIVISTIK," Jakarta: Prestasi Pustaka Publiser, 2011.

[3] Lembaga Administrasi Negara dan Badan Pengawasan Keuangan dan Pembangunan, 2000. Pedoman Penyusunan Pelaporan Akuntabilitas Kinerja Instansi Pemerintah, LAN \& BPKP, Jakarta

[4] J. Mantiri, C. Siwi, and M. Korompis, "The Implementation of Micro Business Development in the Department of Cooperative and SMEs of Minahasa Regency," 2019.

[5] M. Albrow, Bureaucracy, "Universitas College"Cardiff, alih bahasa Rusli Karim dan Totok Daryanto, Tiara wacana, Yogyakarta, 2003.

[6] Peraturan Menteri Agama Republik Indonesia Nomor 41 tahun 2016 Tentang Pengawasan Internal Pada Kementerian Agama

[7] S. Siagian, "Manajemen Sumber Daya Manusia," Inter Aksara, Batam, 1998.
[8] Kementrian Agama Republik Indonesia. 2017.

[9] Peraturan Pemerintah Nomor 53 Tahun 2010 tentang Disiplin Pegawai Negeri Sipil. 